\title{
APPROACHES TO SUPPORT OF AGRICULTURE IN TERMS OF THE EU CAP STRATEGY AMENDMENT
}

\author{
V. Bečvářová
}

Received: November 9, 2009

\begin{abstract}
BEČVÁŘOVÁ, V.: Approaches to support of agriculture in terms of the EU CAP strategy amendment. Acta univ. agric. et silvic. Mendel. Brun., 2009, LVII, No. 6, pp. 19-28

The contribution deals with the principles as well as the economic implications of changes in the agriculture entrepreneurial environment. It denotes, that the vision of the European model of multifunctional agriculture is ever more frequently confronted with new challenges invoked by acceleration of globalization processes. Those qualitatively new requirements to agricultural enterprises behaviour as well as to the state intervention, strictly speaking the Common Agricultural Policy (CAP), in the branch in a framework of the global markets development is notified there. On the basis of analyses of individual development stages and the manner, in which this sector has been legislatively and economically regulated, it is possible to document in the history of CAP EU the radical development of the European agrarian sector in general and how the CAP reacted to this development. The development concerned both the very agriculture and the agrarian sector and its economic position and changes of the social environment itself and the selection of adequate regulation tools corresponding to the environmental development and changes of situation. We can see that significant regional and structural differences are still hidden behind aggregated data about average economic performance of the agrarian sector of the EU and that different approach and priorities for solutions to individual issues can be chosen, provided that the issues have been identified and assessed in an objective manner. At the sometime these findings can be an opportunity to consider to what extent the individual member states are able to take over the existing rules and use conditions imposed by directives of the Community and to what extent we are able to actively assess the situation of the world agrarian markets and adequately respond to the development of the economic environment in broader international contexts. Amendments of the above mentioned conditions become new impulses determining the direction and dynamics of development of the economic environment; if we intend to preserve or improve our competitive strength, it is necessary to adequately respond to them.
\end{abstract}

agriculture, common agricultural policy, competitiveness, rural development, subsidy

The problem of legitimacy of state interferences with economy and the related forms and manifestations of market development have been a permanent key problem of forming the agricultural policy in the whole history of its development in Europe as well as in the world. Even in the today's society, the subject-matters of discussions are looking for suitable options of solutions meeting the defined strategies, selection of concepts, level and forms of state interventions. It s becoming a frequent object of the conflict of opinions between representatives of various interest groups within the agrarian sector, food management as well as in the regional development conceptions.
Under the conditions of transitive economies in general, and in particular in some countries of the central and Eastern Europe, the problem of state interventions into agriculture and application of subsidies with these interventions was even recently presented as an approach absolutely inconsistent with the principles of market economy. The other extreme on the other hand was the unilateral argumentation using the growing subsidy support, or the high level of protection of this field respectively in the most economically advanced countries.

As of the Czech Republic's accession to the European Union in 2004, the overall framework, philosophy as well as level and form of support and 
regulation in agriculture are generally subject to the rules and limits of the EU Common Agricultural Policy (CAP). As early as of the beginning of the nineties of the last century, we have been witnessing and these days also playing a part in changes of this one of the oldest European community policies that is forced to react to the changing internal as well as external economic and social environment. Within the ongoing reforms of this policy, however, there has been ever-wider space opening for decision-making (but also responsibility) of individual member states when specifically fulfilling the general principles of the new CAP model. The overall strategy has been changing and conceptions are being created of such regulation as well as supporting mechanisms, which are far from being a pure reaction to the growing surpluses of agrarian commodities on the growing internal European market. Another ground of the reform steps, which is nevertheless realizable unilaterally, is a change in the perception of the task of agriculture from its original production role in economy up to its today's multifunctional approach.

The vision of the European model of agriculture is ever more frequently confronted with new challenges invoked by acceleration of globalisation processes. This very type of processes is behind a number of changes of economic conditions in agriculture and the agrarian sector in the general, branch as well as regional context. Therefore the forming and development of the world agribusiness, typical with its growing influence of transnational companies, world business chains and food networks, presents other topics to the authors of the agrarian policy, these topics requiring objectification of approaches to solutions of further agricultural development and its role in rural development. There is a growing need of interdisciplinary solutions making use of positive as well as negative knowledge basis of the agrarian economy and policy.

\section{On the question of subsidies into contemporary agriculture in general}

In the current model of agriculture, its production and other non-production activities are narrow-connected with a complex network of interconnected conditional causes and effects in the development of the society in all dimensions (economic, ecological, technological as well as human and social one).

The target solution does have a long-term nature but the dynamics of changes in the environment as combined with the specific aspects of agricultural production makes it necessary to select a complex approach from the very beginning of the solution including the permanent reflection of the effects of reform steps realization at the production as well as non-production level.

Limitation of the risk of negative effects of a strategically unsuitable or short-term purpose-used setting of the flow of subsidies into agriculture, or more precisely into the agrarian sector, and currently also to the rural development generally concerns two problems, namely

1. allocation and selection of the range of income redistribution in terms of strategy and criteria of support to the sector/branch, i.e. legitimacy of subsidies, related to appreciation of the role and setting of preferences in the development of the society within the concerned stage of development,

2. distribution of finances, i.e. decision-making about the form of transfer, its economic costs and effect on the beneficiary's decision making connected with efficiency of subsidies and criteria for reasonable use of the support.

A typical feature of changes of the CAP model is the withdrawal from the support of incomes in agriculture by means of the price support for commodities mostly on the basis of commodity market rules and the transfer to the "simpler" but in terms of economic nature much more complicated systems of subsidies in the form of direct payments and project-conceived structural supports.

These measures are connected also with decentralization in the very decision-making in member countries in relation to priorities in the allocation criteria as well as subsidy distribution. Within the rules and limits defined in the community law while integrating the Union and national budgets, it is without question a positive element. When distributing the sum of the budget finances, there is an opportunity to decide on the solution of specific problems in agriculture in individual countries.

Nevertheless, globalisation processes move the need of theoretical interpretation of the market environment changes as well as the task of regulation interventions further. The neoclassical theory does understand the price as a sufficient incentive for development of liberalized markets, in the same time however, it points out certain criteria related to the full application of the market allocation function in the global context including the hypothesis that goods and services may be cheaper when larger production capacities are used (economy of scale, for example Krugman, 2003). Then the task of regulatory interventions goes into the issues of competitiveness of sectors and solutions of conditions of sustainability under the real conditions in the countries and regions and it is more markedly connected with the category of investments.

Without respecting the key interactions with the surroundings, the very European model of agriculture with a large number of producers dependent on land (of various quality and fertility, which to a considerable extent limits the choice of commodity structure of the agricultural production) might be considered a typical model of the structure of environment with perfect competitiveness and minimization of the effect of agricultural producers on creation of commodity prices basically at all relevant markets. In general, the influence of typical foodstuff market attributes on the basis of the specifics of the offer and demand formation in interaction with the commodity prices on the markets in the long- 
term time horizon can be represented as follows: Fig. 1. ing to a simplified conclusion that under the current circumstances, there is no reason anymore to

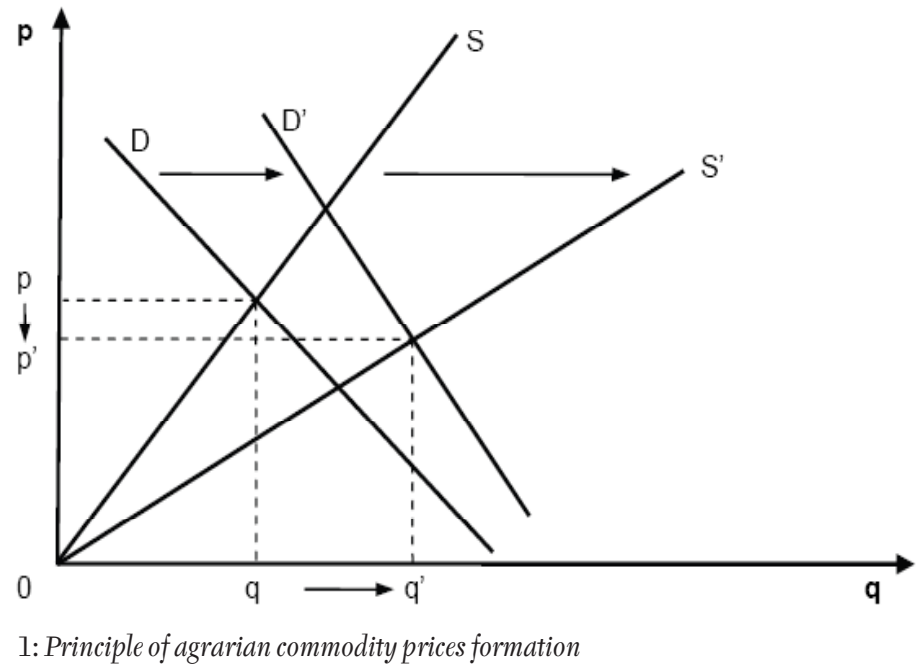

Within the said agrarian market development context, in particular the effects of a slower demand growth are shown, these effects being typical also when reflecting the effect of the population growth including the increased consumption of foodstuff per citizen in general. It is reflected in the waveform, shape as well as a slight move of the demand curve D-D'. On the other side, the market conditions forming and the price creation reflect the considerably more substantial growth of the offer, which is shown in particular in its move and change of inclination from the original curve $S$ to $S$ '. In this case, in a longer-term time horizon, it includes both the partial extension of the managed area and in particular the growth of productivity factors as a result of technological innovations. The unbalanced state based on the new waveform of both curves (D' and S') indeed generally leads to a decrease of the balanced price, namely from $p$ to $p$ '. The above-mentioned preconditions have been in the long-term confirmed by the price development of agricultural products on the world markets generally since beginning of the last century.

The acceleration of globalization processes accompanied both by the increased pressure on agrarian markets liberalizations and by forming the agribusiness ${ }^{1}$ further change the business environment. Agriculture, in its production dimension, has been becoming de facto a part of a considerably wider segment of economy. Its success limits also the ability to fulfil other roles of the sector. Although the abovementioned development tendencies might be tempt- support the production dimension of agriculture, it is a paradox that in this very context of liberalized market, the issues of strategic nature connected with the role and integral objective of this sector in the modern society are becoming ever more important.

They are related to a whole spectrum of problems from the growing risks of supplies, modernization of production systems including establishment of preconditions for foodstuff quality guarantee up to the role of agriculture in the economic and social dimension of the interpretation of self-sufficiency.

\section{Formation of the current Common agricultural policy model}

The policy development concerned both the very agriculture and the agrarian sector and its economic position and changes of the social environment itself and the selection of adequate regulation tools corresponding to the environmental development and changes of situation.

The period of crucial reforms of the original conception of the Common agricultural policy was initiated at the beginning of the nineties of the twentieth century. In 1992, the first important CAP reform (Mac Sharry's one) was adopted, which considerably reduced the support of agriculture on the basis of high market prices and which was to a considerable extent replaced with a commodity-focused compensation payment and which was focused on other directions as well as forms of income support in agriculture. In the same time, the issue of structural changes was reintroduced. ${ }^{2}$ The so-called European model of agri-

1 In detail Bečvářová, The Essence and Economic Context of Agribusiness Formation. MZLU Brno, 2005.

2 These measures had to react not just to the growing expenditure related to the common agricultural policy but also to the obligations from the Uruguay round of GATT and subsequent negotiations of WTO. 
culture started to be pursued much more considerably, in particular following the Austria's accession to the EU. EU espoused the European model of agriculture by the Cork Declaration in 1996. The model respects not only the specifics of European agriculture in terms of greater demands on the methods of agricultural production in a densely populated European area but in particular its benefits in terms of production of positive externalities and public domains in the form of landscape cultural condition maintenance, its population, protection of natural resources and rural social development.

This approach was accepted also by the next reform prepared within the Berlin Convention in 1999 as a part of measures aimed at growth of effectiveness of the European Communities activity known as Agenda 2000. Despite certain compromises in the CAP reform at the Berlin summit when the European Commission had originally suggested more radical changes in liberalization as well as subsequent support system, in general, preconditions for further minimization of market deformations were created. A new CAP element was implemented, the so-called national envelopes, which allowed individual members states to support the conception of structural development by commodity selection, when national support would be provided according to national criteria up to the amount of the set limits.

The common policy of rural development, environmental protection and multi-function role of the European agriculture was adopted officially. In this context, the second CAP Pillar is created that is focused on support of structural changes and the rural development policy.

The budget finances for rural development were reinforced and rules in this area were simplified. In the same time, the principal of voluntary direct support modulation by member states was adopted, which allows transferring a portion of direct payments to rural development measures. The above-mentioned decisions in relation to the agricultural policy meant a reduction of agrarian expenditure as in 2004; EU was expanded by 10 new members while the agrarian policy costs had to be solved only within the budget stabilized in this manner.

In 2003, the European Commission decided to adopt an offensive approach to negotiations about the agricultural chapter in WTO and it used its mandate granted by the Council in order to prepare the Mid-Term CAP Review in 2002. In addition to the CAP review, a motion was presented of a relatively crucial other reform steps and to reinforce the flexibility for member states when applying the future CAP. The decisive principles of the CAP reform based on the Mid-Term Review (the Fishler's reform) may be summed up by means of the following spheres:

- separating direct payment from the production ("decoupling") when henceforth, a farmer was to receive one support amounting to the sum of individual direct payments in the reference period, this payment being transferable, demisable and saleable,
- meeting environmental protection and foodstuff safety standards as a precondition for provision of direct payments,

- applying modulation, which means that by direct payments reduction, resources will be generated to reinforce rural development support,

- implementing the tool of financial discipline that will allow, in the event of a treating overstepping of the EU agrarian expenditure limit, a lump-sum reduction of the direct payments expenditure,

- extending the range of rural development programs by measures aimed at reaching the standards of environmental protection, foodstuff safety and animal welfare, improved quality of agricultural products, associating of producers and partial adjustment of existing conditions of the current rural development titles,

- implementing the support of energetic crop growing,

- reducing the intervention prices of diary product and other market measures that are supposed to ensure a better position of EU during WTO negotiations,

- the option of simplifying the CAP administration system for member states as well as for farmers (it depends on selection of the system by the member state).

In general, it created a wider space for selection of measures supporting growth of agricultural competitiveness in individual member states in the international context. In the same time, it reinforced the support of rural development to the prejudice of market measures (growth of the second CAP pillar) and increasing safety of foodstuffs on the EU market.

In terms of the overall conception of supports in the European agrarian policy, the next step in the changing philosophy of the basic support for agricultural businesses, which was supposed to lead to a more consequential separation of the support of agricultural business from the specific production structure and volume of secured production on the basis of uniform direct payments, proved to be a key one.

Generally, this concerned implementation of another reform step following up the strategy adopted as early as within CAP I in 1992 and Agenda 2000 (CAP II), which was shown in further reduction of the direct price support and other market interventions and a change of the form as well as objectives of other tools of agricultural support within the European Union. The transfer to direct payments within the reform was conditioned also by measures of cross control or cross-compliance control respectively. In practice, this means that payment of the uniform payment per farm as well as other forms of direct payments is conditions by meeting the conditions of 18 directives and regulations concerning environmental protection, foodstuff safety, animal and plant health and animal welfare. The modulation means a transfer of a portion of direct payments into the rural development measures. This system was 
launched in 2005 with the rate of $3 \%$. The rate was increased to $4 \%$ in 2006 and to $5 \%$ in 2007.

\section{Approaches to complex solution of agricultural and rural support}

The idea of a complex solution of further development of the agrarian sector including the necessary reinforcement of criteria of environmental and landscape protection and participation in the overall rural development became topical at the times when the EU, within WTO negotiations, became more open to business exchange and thereby to the pressure of competitive production from world markets.

It meant new challenges for the further strategy of the European agriculture, to which EU reacted by restricting the support in the Pillar I and the growing importance of measures within the CAP Pillar II.

The common interest in support of agriculture in its production as well as non-production context as a vehicle of rural development became a part of the EU strategy and subsequently the Rural Development Programs (RDP) of the 27 EU member states. It was reflected also in the EC regulation 1698/2005 on establishment of the European Agricultural Fund for Rural Development, which became valid as of January 2007. Strategic priorities were defined within 4 axes, for which also the minimum limits for distribution of finances were laid down.

- AXIS 1 is focused on support of competitiveness of the agriculture, agrarian and forestry sector (a minimum of $10 \%)$.
- AXIS 2 is focused on creation of background for improvement of the environment and landscape (a minimum of $25 \%$ ).

- AXIS 3 is aimed at support of quality of live in rural regions, by its approach, it oversteps agricultural issues and it is related to diversification of rural activities (a minimum of $10 \%$ ).

- AXIS 4 - LEADER (a minimum of 5\%, 2.5\% for new countries, a measure based on local development strategies within micro-regions)

The comparison of strategies of agricultural and rural development support may to a certain extent contribution to development of a notion of how distinct the differentiation is in today's approaches to the agrarian sector in individual EU countries within the "uniform" CAP framework.

Different approaches to fulfilment of the philosophy of agricultural support as a key factor of this development are suggested by the very general international comparisons of the Rural Development Programs in individual $27 \mathrm{EU}$ member states and by the conception of their reflecting into the presumed use of EAFRD finances within its individual axes in the period 2007-2013. ${ }^{3}$

The overall strategies of the member states' agrarian policy itself within specification of the philosophy and integrated support of agricultural development, agrarian sector and rural regions within the CAP reform are to a certain extent reflected in the choice of priorities and importance of expenditure within individual EAFRD axes.

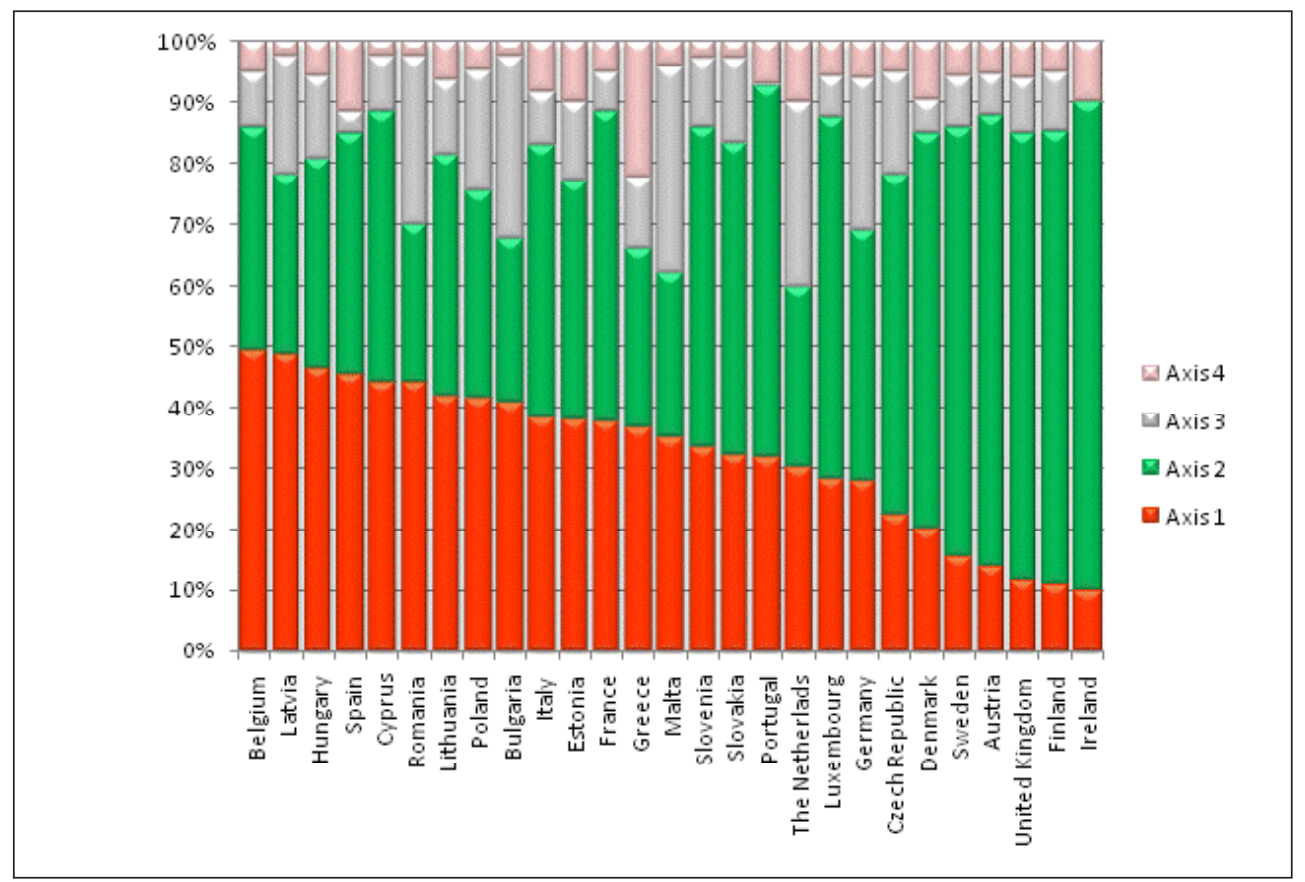

2: Conception of EAFRD Use in 27 EU Countries with Expenditure Distribution by Axes in the Period 2007-2013 Source: Rural Development in the EU, Statistical and Economic Information DG Agri and RD, 2008

3 For the said comparisons, one used statistic supporting documents of member states published by EC, DG Agriculture and Rural Development to the Rural Development Programs for the period 2007-2010, or 2013 respectively. 
As it follows from comparison of proportions of the expected allocation of support from the European Agricultural Fund finances in individual axes, even when the set minimum share (10:25:10:5) is complied with, there are considerable differences in the overall conception of the solution. They reflect the selected agrarian policy strategy of the concerned state and hence also the interest and engagement in the growth of business entities competitiveness within the agrarian sector on the European and world markets. This includes in particular making use of the option to capture modern trends and manufacturing processes, support of innovations (namely not limited to the technological ones) and creation of preconditions for meeting the quality standards and environmental criteria when running an agricultural production and its processing for the future.

In this context, much is suggested by the comparison of the proportion of competitiveness support expenditure, i.e. in particular a comparison of the proportion of axis 1 measures (business modernization programs, investments, adding value) and the "agro-environmental" aspect, i.e. axis 2 (connected inter alia with payments for natural and other disadvantages within LFA and payments within the Natura area) in individual countries.

The requirement of reinforcing axis 2 is generally met. Differences in terms of the expected program realization in individual countries are nevertheless very considerable. If we do not consider the conception of agricultural support solution in the agrarian policy of the British islands countries, where there is a long-term environmentally focused support that is complexly and effectively interconnected with production aspects, in particular with beef-raising and breeding of other ruminants and milk production in the whole of the vertical line, then the CR with its preference of axis 2 ranks with the northern countries and the mountainous Austria.

On the other side, the share of axis 1 conceived in particular to directly support innovations and creation of prerequi- sites of business competitiveness in basic industries as well as in subsequent stages, is the lowest one in the CR not just from the new member states that are in addition forced to cope with a lower level of direct payments in basic industries.

A higher share of axis 1 in the overall structure, namely with a considerably higher engagement of other public as well as private expenditure, is at this state of development preferred even in such decisive producing countries of the original EU 15 like France, Germany, Netherlands, Belgium but also Spain and Italy.

If we derived the strategy of supporting modernization of agriculture in individual countries from the expected use of individual spheres of measures within the axis 1 itself, which may be generally understood as a "pillar for competitiveness", even in this case there is a relatively considerable differentiation in the selection or strictly speaking the importance of support of individual spheres of measures.

In general within the axis 1, at the first places, there are measures for modernization of agricultural businesses, restoration of production potential and adding value to agricultural and forestry products in all countries; nevertheless, their importance differs also in this area. When we compare the structure of the considered allocation of finances in axis 1 in the CR with the decisive EU producers, i.e. France and Germany, then it is once again the Czech agrarian policy, which requires a lower share of supports for agricultural modernizations and innovations than the programs of both abovementioned countries. Although the programs and sub-measures within individual axes are published gradually, which to a certain extent allows reacting also to the development and the current situation, the access of the CR to the competitiveness support on the basis of production basis modernization and technological equipment of agricultural businesses cannon be considered sufficiently reacting to the requirements of the current development model and fulfilment of the production role of the agrarian sector.

\section{SUMMARY}

A change in the CAP strategy, gradually implemented by means of steps of individual reforms as early as since the nineties of the twentieth century up to the solutions within the Health Check generally meant a withdrawal from the agriculture support on the basis of supporting prices of agricultural commodities as well as reactions to acceleration of globalization processes radically changing also the position of farmers. The development has confirmed that in a whole range of connected markets, demand has been really establishing itself. It reacts to the development of world stock; it determines the conditions of offer on markets of most agrarian commodities much more flexibly than the agrarian policy measures ever can.

This in the same time changes the essence and further reinforces the risk of producers facing the market strength of purchasers under conditions of imperfect transfer of demand conditions in the market sequence from the consumer to the basic industry. These days, the transformation of demand for products with agricultural nature and in particular the possibility and the ability of its structural fulfillment in general define the space for producers of agricultural raw materials and in its effects also the economic dimension of agricultural production in the concerned region. Nevertheless, this change requires also a new approach to the regulating interventions and supporting measures in the agrarian sector. Another dimension in the multi-function approach to its role was gained by the European ag- 
riculture in connection with emphasizing its role within the rural development. In the same time, there is a space opening for a wider participation of member countries in creation of agriculture support conceptions according to the specifics and priorities of the individual member states.

A change of the overall strategy and selection of CAP tools is typical by the growth of the share of transfers/subsidies requiring income distribution. Nevertheless, this generally increases the dependence of farmer and rural support on expenditure of taxpayers. In the current stage, this applies in particular to allocation of support and use of the gradually balancing direct "decoupled" payments in compensation of lower income of the sector within the whole EU 27. The difference within the level of direct payments in agriculture of new member states, provided that they equal the original EU 15 only in 2013, is one of the problems directly concerning the comparability of conditions and possibilities of development of the Czech agriculture as a modern sector capable of competition within the common market. Under the today's fall of the agricultural producers' price level and the incomparable level of income compensation by means of other tools, the model of basic industry financing system does not contribute to this development.

The risk connected with the realistic option of creating preconditions of producer competitiveness on the common market is increasing, namely in horizontal as well as vertical relations of a modern sector. This problem becomes serious in particular under the conditions of the emerging financial crisis accompanies with a pressure of connected processing and trading elements on further reduction of food consumer prices.

Just when applying the current model, in consideration of the selected tools (subsidies with a relatively high proportion of transaction costs), it is necessary to objectively consider the level, the effectiveness and the benefits of such allocated resources in general as well as in terms of the possibility of developing business entities in typically productive regions of the state territory.

The effectiveness of subsidy allocation mainly depending on income redistribution at the level of member states as well as the Community, namely both as concerns direct payments and on the basis of selection of individual axis priorities, is conditioned by a system-connected agrarian and structural policy. In countries of the original EU 15, it has its history, experiences as well as strategy of support and regulation reflecting the current as well as the future trends of the sector development in the global world. It has proved the positives and risks of steps taken to support specific regions. New member states, and the Czech Republic among them, are only acquiring such experiences.

Therefore the ability to meet the philosophy of complexity and mutual dependence of agricultural and rural development measures, which is systematically interconnected with the choice of priorities, seems to be strategically crucial also for the success of the next stages of reforms steps within the common European policy and its implementation under specific conditions of individual member states. A certain level of independence in decision-making of individual member states in the current state should therefore make use of the current (and no doubt also time-limited) means in particular in order to create preconditions for development of modern production meeting the requirements of healthy foodstuff production while meeting parameters of natural resources protection so that in its complex effect, it contributes to the development of modern agriculture as one of the decisive vehicles of rural regions development and limits the dependency of the sector as well as the rural regions on subsidies in rather a long-term horizon.

\section{SOUHRN}

\section{Přístupy k podpoře zemědělství v rámci změn strategie SZP EU}

Změna strategie SZP, postupně naplňovaná kroky jednotlivých reforem již od počátku devadesátých let dvacátého století až po současné řešení v rámci Health Check, obecně znamenala ústup od podpory zemědělství na bázi podpory cen zemědělských komodit a to v podmínkách akcelerace globalizačních procesů zásadně měnících postavení zemědělců v celkovém rozvoji evropského regionu. Vývoj potvrdíl, že v celé škále navazujících agrárních trhů se skutečně prosazuje poptávka. Reaguje na vývoj světových zásob, určuje podmínky nabídky na trzích většiny agrárních komodit daleko pružněji, než to dokážou opatření agrárních politik.

Tím se současně mění podstata a dále posiluje riziko výrobců čelících tržní síle odběratelů při nedokonalém přenosu podmínek poptávky v sekvenci trhů od spotřebitele až k prvovýrobě. Transformace poptávky a především možnost a schopnost jejího efektivního strukturálního naplnění dnes v zásadě již vymezují prostor výrobcům zemědělských surovin a ve svých důsledcích i ekonomický rozměr zemědělské výroby v daném regionu. Tato změna však vyžaduje i nový přístup k regulačním zásahům a podpůrným opatřením v agrárním sektoru.

Změny v koncepci evropské zemědělské politiky byly proto i z výše uvedených důvodů proti původním př̀edstavám výraznější. Při omezení podpory cen byly obecně voleny kvalitativně jiné formy regulace reagující na rostoucí tlak na liberalizaci trhů, na rủst poptávky po potravinách v rozvojovém světě i na vnitřní potřebu prosazení a dodržování ekologičtějších postupů při produkci kvalitních po- 
travin. Posílením role strukturálně a environmentálně profilovaného Pilíře II př̀i odstraňování bariér globalizujícího se trhu se současně otevírá prostor pro širší účast členských zemí na tvorbě koncepcí podpory zemědělství podle specifik a priorit konkrétního členského státu. Globalizace prostředí přitom současně mění podmínky, strukturu i profil ekonomicky životaschopných farem, které tvoří základ prosperujícího sektoru. Dnes již musejí tyto subjekty obstát v konkurenci nejen jako partner vertikálních vazeb prosazujícího se agrobyznysu, ale čelit i disparitě v utváření horizontálních podmínek konkurence zemědělských výrobců na evropském trhu.

Změna celkové strategie a volba nástrojů SZP je typická ri̊stem podílu transferů/dotací vyžadujicích redistribuci dúchodu. Tím však obecně zvyšuje závislost podpory zemédèlců a venkova na výdajích daňových poplatníkü. V současné fázi se týkají především alokace podpor a užití postupně se vyrovnávajících prímých „decoupled“plateb v kompenzaci nižších př́íjmů odvětví v celé EU 27. Rozdíl v úrovni přímých plateb v zemědělství nových členských zemí, za předpokladu vyrovnání s původní EU15 až v roce 2013, je jedním z problémů, který se bezprostředně týká srovnatelnosti podmínek a možností rozvoje českého zemědělství jako moderního sektoru schopného konkurence již v rámci společného trhu. Model systému financování prvovýroby při dnešním poklesu hladiny cen zemědělských výrobců a nesrovnatelné úrovni kompenzace př́ímů pomocí dalších nástrojů k tomuto vývoji nepřispívá.

Zvyšuje se riziko spojené s možností tvorby předpokladů konkurenceschopnosti výrobců na společném trhu, a to v horizontálních i vertikálních vazbách moderního sektoru. Tento problém nabývá na vážnosti zejména v podmínkách finanční krize provázené tlakem navazujících článků zpracování a obchodu na další snižování hladiny spotřebitelských cen potravin. Částečné řešení nabízí efektivní využití prostředků určených na podporu strukturálního rozvoje při vhodném načasování a prioritizaci. Inspiraci v celé škále strategických přístupů jednotlivých zemí k daným otázkám rozvoje zemědělství ve smyslu integrovaného rozvoje zemědělství a venkova lze nalézt již při zkoumání priorit Programů rozvoje venkova jednotlivých členských zemí a návrhů na využití zdrojů financování z prostředků Evropského zemědělského fondu pro rozvoj venkova od roku 2007. Již z výsledků mezinárodních komparací vyplývají poměrně významné rozdíly v koncepci př́istupů k podpoře produkční a mimoprodukční role agrárního sektoru v členských zemích.

S ohledem na charakter zvolených nástrojů (dotace s relativně vysokým podílem transakčních nákladů) je právě při aplikaci současného modelu nezbytné objektivně posoudit míru, účinnost a př́ínos takto alokovaných zdrojů obecně i z hlediska možnosti rozvoje podnikatelských subjektů v typicky produkčních oblastech území státu. Problém se netýká pouze předpokladů úspěšnosti těchto subjektů v moderně se formujícím agrobyznysu, tj. předpokladů konkurenceschopnosti podniků z produkčně nejvhodnějších oblastí v rozměru domácího, evropského, resp. světového agrárního trhu, ale i možnosti skutečné realizace jejich přínosu k tvorbě ekonomického a sociálního zázemí rozvoje venkovských regionů.

Efektivnost alokace dotací převážně závisející na redistribuci důchodů na úrovni členských zemí i Společenství je podmíněna systémově propojenou agrární a strukturální politikou. V zemích původní EU 15 má svou historii, zkušenosti i strategii reflektující současné i budoucí trendy vývoje sektoru v globálním světě. Ukázala pozitiva a rizika kroků přijímaných v podpoře konkrétních regionů. Nové členské země a mezi nimi i Česká republika tuto zkušenost teprve získávají. Je nesporné, že problém oprávněnosti a míry redistribuce společenských zdrojů ve prospěch venkovských oblastí bude i v dalším období jedním z nejvíce diskutovaných. Bude však stále výrazněji determinován kritériem maximální efektivnosti a tlakem na omezování tohoto typu státních zásahů.

Schopnost naplnění filozofie komplexnosti a vzájemné podmíněnosti opatření rozvoje zemědělství a venkova systémově spojená s volbou priorit se proto jeví jako strategicky klíčová i pro úspěch dalších fází reformních kroků společné evropské politiky a její realizace v konkrétních podmínkách jednotlivých členských zemí. Určitá samostatnost v rozhodování jednotlivých členských států v dané etapě by proto měla využít současných (a nesporně i časově omezených) prostředků především pro vytvoření předpokladů rozvoje moderní výroby splňující požadavky produkce zdravých potravin při dodržení parametrů ochrany přírodních zdrojů tak, aby ve svém komplexním efektu přispěla k rozvoji moderního zemědělství jako jednoho z rozhodujících nositelů rozvoje venkovských regionů a omezila závislost sektoru i venkova na dotacích v dlouhodobějším horizontu.

zemědělství, společná zemědělská politika, konkurenceschopnost, rozvoj venkova, dotace

The paper was developed within the Research Project of MUAF in Brno, MSM 6215648904, as a part of the solution to thematic direction No. 4 "The development tendency of agribusiness, forming of segmented markets within commodity chains and food networks in the process of integration, globalization and changes of agrarian policy". 


\section{REFERENCES}

ANDERSON, K., HAYAMI, Y., 1986: The political economy of agricultural protection, London.

ANDERSON, K., SWINNEN, J., 2008: Distortions to agricultural incentives in Eastern Europe and Central Asia, World Bank, ISBN 978-0-8213-7420-7, Washimgton D.C.

BEČVÁŘOVÁ, V., 2001: The general economic level influence on branch support amount. Acta Universitatis Agriculturae et Silviculturae Mendelinae Brunensis, Vol. IL, No. 6, 103-114, ISSN 1211-8516

BEČVÁŘOVÁ, V., 2005: Agribusiness - the Scope as well as the Opportunity for Contemporary Agriculture. In. Agricultural Economics, Vol. 51, (7), s. 285-292. ISSN 0139-570X

BEČVÁŘOVÁ,V., 2007: Potentialities for decoupled payments to affect structural changes in contemporary production agriculture. Acta scientiarum polonorum. SGGW Warszawa, sv. 6, č. 3, s. 3-10. ISSN1644-0757

EUROPEAN COMMISSION Agri-environment Measures, Overview on General Principles, Types of Measures and Application Brussels: 2005 EC, Directorate General for Agriculture and Rural Development [online].

EUROPEAN COMMUNITIES, Council Regulation (EEC) No. 2078/92 of 30 June 1992 on agricultural production methods compatible with the requirements of the protection of the environment and the maintenance of the countryside, 2006 [online]
FISCHLER, F., 2002: Towards sustainable Farming a midterm review of CAP. Luxembourg: Office for Official Publications of the EC. ISBN 92-894-4131-3.

GARDNER, B. L., 1989: Economic theory and farm politics. American Journal of Agricultural economics, Vol. 71, pp. 1165 -1171.

HARVEY, D., 1997: Extensions and Political analysis of the CAP The Common Agricultural Policy, CAB International, mimeofeaph, $23 \mathrm{pp}$.

ROBERTSON, R., 1992: Globalization: Social Theory and Global Culture. London, Sage.

STIGLITZ, J. E., 1987: Some theoretical aspects of agricultural policies, World Bank Research Observer, Washington D.C.

SWINNEN, J., 1994: A positive theory of agricultural protection. American Journal of Agricultural economics, Vol. 76, pp. 1-14

WILLIAMSON, O. E., 1985: The Economics Institutions of Capitalism: Firms, Markets, Relational Contracting. New York, London.

WILLIAMSON, O. E., 1989: Transaction Cost Economics, in: Schmalensee, Richard, Willig, Robert D. (ed.): Handbook of Industrial Organization, Vol. I, Amsterdam.

WITZKE, H., NOLEPPA, S., SCHWARZ, G., 2008: Global agricultural market trends and their impacts on European Union agriculture. HU, Berlin WP Nr. 84. 
